\title{
Shewanella xiamenensis sp. nov., isolated from coastal sea sediment
}

\author{
Jiexun Huang, ${ }^{1}$ Baolin Sun ${ }^{1}$ and Xiaobo Zhang ${ }^{2,3}$ \\ ${ }^{1}$ Hefei National Laboratory for Physical Sciences at Microscale and School of Life Sciences, \\ University of Science and Technology of China, Hefei, Anhui 230027, PR China \\ ${ }^{2}$ College of Life Sciences, Zhejiang University, Hangzhou 310058, PR China \\ ${ }^{3}$ Key Laboratory of Marine Biogenetic Resources, Third Institute of Oceanography, State Oceanic \\ Administration, 178 Daxue Rd, Xiamen 361005, PR China
}

\begin{abstract}
A Gram-negative, motile, rod-shaped bacterium, strain $S 4^{\top}$, was isolated from coastal sediment collected off Xiamen, China. The physiological and biochemical features of strain $S 4^{\top}$, determined using the API 20NE, API ZYM and Biolog GN2 systems, were similar to those of members of the genus Shewanella. Phylogenetic analyses based on 16S rRNA and gyrB gene sequences placed strain $S 4^{\top}$ in the genus Shewanella, and it was most closely related to Shewanella oneidensis and related species. DNA-DNA hybridization demonstrated only $11.9-30.4 \%$ relatedness between $S 4^{\top}$ and the type strains of related Shewanella species. On the basis of phylogenetic and phenotypic characteristics, strain $S 4^{\top}$ is classified in the genus Shewanella as a representative of a distinct novel species, for which the name Shewanella xiamenensis sp. nov. is proposed. The type strain is $S 4^{\top}$ (=CCTCC M $209017^{\top}=J C M 16212^{\top}$ ).
\end{abstract}

Since the genus Shewanella was described (MacDonell \& Colwell, 1985), numerous Shewanella species have been isolated from various environments, such as fresh water and the ocean (Hau \& Gralnick, 2007). At the time of writing, at least 49 recognized distinct species belong to the genus Shewanella. Key features of the members of this genus include the ability to use a diverse range of electron acceptors for anaerobic respiration (Nealson \& Scott, 2006) and the ability to grow at low temperatures (Bozal et al., 2002). In this study, a novel Gram-negative, mesophilic, rod-shaped bacterium of the genus Shewanella, strain $\mathrm{S}^{\mathrm{T}}$, is described.

Strain $\mathrm{S} 4^{\mathrm{T}}$ was obtained from a sediment sample that was collected from a coastal area of Xiamen, China. The novel strain was isolated by a standard dilution plating technique on Luria-Bertani (LB) agar supplemented with $40 \mathrm{mM}$ sulfur and $30 \mathrm{mM}$ lactate $\left(\mathrm{LB} / \mathrm{S}^{0} / \mathrm{Lac}\right.$; Moser \& Nealson, 1996). The plates were first incubated aerobically at $30{ }^{\circ} \mathrm{C}$ for $24 \mathrm{~h}$ to obtain aerobic isolates. This collection of

Abbreviation: TMAO, trimethylamine $\mathrm{N}$-oxide.

The GenBank/EMBL/DDBJ accession numbers for the nucleotide sequences reported in this study are respectively FJ589031 and FJ589040 (16S rRNA gene and partial gyrB gene sequence of strain $S 4^{\top}$ ) and FJ589036 and FJ589041 (partial gyrB gene sequences of $S$. profunda DSM $15900^{\top}$ and S. basaltis JCM $14937^{\top}$ ).

Comparisons of fatty acid and isoprenoid quinone profiles and detailed DNA-DNA hybridization and 16S rRNA gene and gyrB sequence similarity results are available as supplementary material with the online version of this paper. colonies was then screened for sulfur reduction using an anaerobic chamber (Forma Anaerobic System; model 1029) maintained with a $\mathrm{CO}_{2} / \mathrm{H}_{2} / \mathrm{N}_{2}(5: 10: 85)$ atmosphere. Orange-coloured colonies showing clear zones were considered positive for sulfur reduction and were further subcultured by streaking on fresh plates for at least three rounds in order to obtain pure cultures. One isolate was purified and designated $S 4^{\mathrm{T}}$. For long-term storage, strain $\mathrm{S}^{\mathrm{T}}$ was stored at $-80{ }^{\circ} \mathrm{C}$ in marine broth 2216 (Difco) supplemented with $15 \%(\mathrm{v} / \mathrm{v})$ glycerol.

Phenotypic properties of strain $S 4^{\mathrm{T}}$ such as the utilization of various substrates as carbon and energy sources, nitrate reduction, catalase and oxidase activities, gelatin liquefaction, lysine decarboxylase activity and the ability to hydrolyse starch, alginate and casein were characterized using standard procedures (Smibert \& Krieg, 1994). Gramstaining, cell morphology and flagellum type were examined by light microscopy (Nikon E600) and transmission electron microscopy using exponentially growing cells. The $\mathrm{pH}$ and temperature ranges for growth were examined in marine broth 2216. Tests for salt tolerance were carried out in LB broth without $\mathrm{NaCl}$. Anaerobic respiration was examined in a defined medium (Myers \& Nealson, 1990) containing an electron acceptor [ferric citrate, fumarate, amorphic ferric oxide, trimethylamine $\mathrm{N}$ oxide (TMAO), nitrite, thiosulfate or selenite] at appropriate concentrations using lactate as an electron donor. Additional phenotypic characteristics were determined by using API ZYM and API 20NE test strips and Biolog GN2 
microplates (Makemson et al., 1997). The DNA G+C content of strain $\mathrm{S}^{\mathrm{T}}$ was $46 \mathrm{~mol} \%$, which was determined using reversed-phase HPLC (Tamaoka \& Komagata, 1984). Morphological, physiological and biochemical characteristics of strain $\mathrm{S}^{\mathrm{T}}$ are presented in Table 1 and in the species description.

The cellular fatty acid composition was analysed following a method reported previously (Svetashev et al., 1995). Cell mass of strain $S 4^{\mathrm{T}}$ was harvested from a loop of culture grown on marine broth 2216 . The cellular fatty acid profile of strain $\mathrm{S}^{\mathrm{T}}$ contained large amounts of straight-chain (saturated and unsaturated), branched-chain and hydroxy fatty acids; the complete fatty acid composition is given in Supplementary Table S1, available in IJSEM Online. The major fatty acids of strain $S 4^{\mathrm{T}}$ were iso- $\mathrm{C}_{15: 0}, \mathrm{C}_{16: 1} \omega 7 \mathrm{c}$ and/or iso- $\mathrm{C}_{15: 0}$ 2-OH, $\mathrm{C}_{16: 0}$ and $\mathrm{C}_{17: 1} \omega 8 \mathrm{c}$ (total of $66.9 \%)$. This fatty acid profile was similar to those of related Shewanella species.

Analysis of respiratory quinones was carried out by the Identification Service and Dr Brian Tindall, Deutsche Sammlung von Mikroorganismen und Zellkulturen GmbH (Braunschweig, Germany). Strain $S 4^{\mathrm{T}}$ contained both menaquinones and ubiquinones as isoprenoid quinones. The major menaquinone was MK-7 (58\%) and the predominant ubiquinones were Q-7 and Q-8, at peak area ratios of 54 and $43 \%$, respectively. The ubiquinone composition of strain $\mathrm{S}^{\mathrm{T}}$ strongly resembled those of Shewanella oneidensis and Shewanella putrefaciens (Supplementary Table S2). However, strain $\mathrm{S}^{\mathrm{T}}$ contained more MMK-7 (35\%) than did S. oneidensis $(6 \%)$ or S. putrefaciens (7\%) (Venkateswaran et al., 1999).

Genomic DNA was extracted using an E.Z.N.A. Bacterial DNA kit (Omega) following the manufacturer's instructions for DNA $\mathrm{G}+\mathrm{C}$ content determination, 16S rRNA and $g y r B$ gene amplification and DNA-DNA hybridization. The nearly complete $16 \mathrm{~S}$ rRNA gene was amplified with primers $8 \mathrm{~F}$ and $1525 \mathrm{R}$, as described previously (Coates et al., 2001). Almost entire gyrB genes of strain $S 4^{\mathrm{T}}$, Shewanella profunda DSM $15900^{\mathrm{T}}$ and Shewanella basaltis JCM $14937^{\mathrm{T}}$ were amplified and sequenced using degenerate primers UP-1 and UP-2r (Yamamoto \& Harayama, 1995). These gene sequences were aligned and compared to the GenBank nucleotide database using an online BLAST search. Phylogenetic trees were constructed with the neighbour-joining method using the MEGA software (Tamura et al., 2007). DNA-DNA hybridization was performed as described by Ezaki et al. (1989). Hybridization of each sample was examined with five replications; the highest and lowest values for each sample were excluded, and the mean of the three remaining values was reported as the result.

A 1535 bp fragment representing almost the entire $16 \mathrm{~S}$ rRNA gene of strain $\mathrm{S} 4^{\mathrm{T}}$ was amplified and sequenced in this study. This sequence was compared with those of the
Table 1. Phenotypic characteristics of strain $S 4^{\top}$ (Shewanella xiamenensis sp. nov.) and type strains of related Shewanella species

Strains: $1, S$. xiamenensis sp. nov. $\mathrm{S}^{\mathrm{T}} ; 2$, S. oneidensis ATCC $700550^{\mathrm{T}}$; 3, S. putrefaciens ATCC $8071^{\mathrm{T}}$; 4, S. profunda DSM $15900^{\mathrm{T}}$; 5, S. decolorationis JCM $21555^{\mathrm{T}}$; 6, S. baltica DSM $9439^{\mathrm{T}} ; 7$, S. hafniensis NBRC $100975^{\mathrm{T}}$; 8, S. morhuae NBRC $100978^{\mathrm{T}}$; 9, S. glacialipiscicola NBRC $102030^{\mathrm{T}}$. All strains are positive for oxidase and catalase, reduction of nitrate to nitrite and growth at $4{ }^{\circ} \mathrm{C}$ and in the absence of $\mathrm{NaCl}$. All strains are negative for production of urease and arginine dihydrolase, growth in the presence of $10 \% \mathrm{NaCl}$ and growth on adipate. +, Positive reaction; $(+)$, weakly positive reaction; -, negative reaction; ND, no data available. Data were obtained in this study or taken from Venkateswaran et al. (1999), Nozue et al. (1992), Satomi et al. (2003, 2006, 2007), Toffin et al. (2004), Xu et al. (2005), Ziemke et al. (1998) and Fonnesbech Vogel et al. (2005).

\begin{tabular}{|c|c|c|c|c|c|c|c|c|c|}
\hline Characteristic & 1 & 2 & 3 & 4 & 5 & 6 & 7 & 8 & 9 \\
\hline $\begin{array}{l}\text { DNA G + C content } \\
(\mathrm{mol} \%)\end{array}$ & 46 & 45 & 45 & 45 & 49 & 46 & 47 & 44 & 44 \\
\hline \multicolumn{10}{|l|}{ Growth at/in: } \\
\hline $37{ }^{\circ} \mathrm{C}$ & + & + & + & + & + & - & - & - & - \\
\hline $40{ }^{\circ} \mathrm{C}$ & - & + & - & - & + & - & - & - & - \\
\hline $6 \% \mathrm{NaCl}$ & + & - & - & + & - & + & + & - & - \\
\hline \multicolumn{10}{|l|}{ Production of: } \\
\hline Gelatinase & + & + & $+1-$ & + & + & + & + & + & + \\
\hline Amylase & - & - & - & + & - & - & ND & ND & ND \\
\hline$\beta$-Glucosidase & + & - & $(+)$ & - & $(+)$ & $\mathrm{ND}$ & + & + & - \\
\hline $\begin{array}{l}\text { Fermentation of D- } \\
\text { glucose }\end{array}$ & + & - & - & + & + & - & - & - & - \\
\hline \multicolumn{10}{|l|}{ Utilization of: } \\
\hline$\alpha$-Cyclodextrin & + & $\mathrm{ND}$ & - & ND & - & + & $\mathrm{ND}$ & ND & $\mathrm{ND}$ \\
\hline Dextrin & + & $\mathrm{ND}$ & - & ND & - & + & ND & ND & ND \\
\hline Glycogen & $(+)$ & $\mathrm{ND}$ & - & ND & - & + & $\mathrm{ND}$ & $\mathrm{ND}$ & $\mathrm{ND}$ \\
\hline Tween 80 & + & $\mathrm{ND}$ & + & ND & - & + & $\mathrm{ND}$ & ND & ND \\
\hline Gentiobiose & - & ND & - & ND & - & + & $\mathrm{ND}$ & ND & $\mathrm{ND}$ \\
\hline Cellobiose & - & $\mathrm{ND}$ & - & - & + & + & ND & $\mathrm{ND}$ & $\mathrm{ND}$ \\
\hline $\begin{array}{l}N \text {-Acetyl- } \\
\text { glucosamine }\end{array}$ & + & + & + & - & + & + & + & + & + \\
\hline$\alpha$-Hydroxybutyrate & + & $\mathrm{ND}$ & - & ND & - & - & $\mathrm{ND}$ & ND & $\mathrm{ND}$ \\
\hline Caprate & + & - & - & + & + & - & $\mathrm{ND}$ & - & ND \\
\hline Glutamate & - & ND & ND & + & + & ND & ND & ND & ND \\
\hline Gluconate & - & - & - & - & - & + & + & + & + \\
\hline D-Galactose & - & + & + & - & - & $\mathrm{ND}$ & ND & ND & ND \\
\hline D-Glucose & + & - & - & - & + & + & + & - & - \\
\hline Citrate & - & - & - & + & - & + & + & - & - \\
\hline Sucrose & + & - & - & - & + & + & - & - & - \\
\hline Malate & + & - & + & - & + & + & + & + & + \\
\hline Maltose & + & - & - & + & + & + & + & - & - \\
\hline Lactate & + & + & + & + & + & + & + & - & + \\
\hline Arabinose & + & - & - & + & - & - & - & - & ND \\
\hline \multicolumn{10}{|l|}{ Reduction of: } \\
\hline Nitrite & + & + & + & - & + & + & $\mathrm{ND}$ & ND & $\mathrm{ND}$ \\
\hline Thiosulfate & + & + & + & - & + & $\mathrm{ND}$ & + & + & + \\
\hline TMAO & + & + & - & - & + & $\mathrm{ND}$ & + & + & + \\
\hline
\end{tabular}




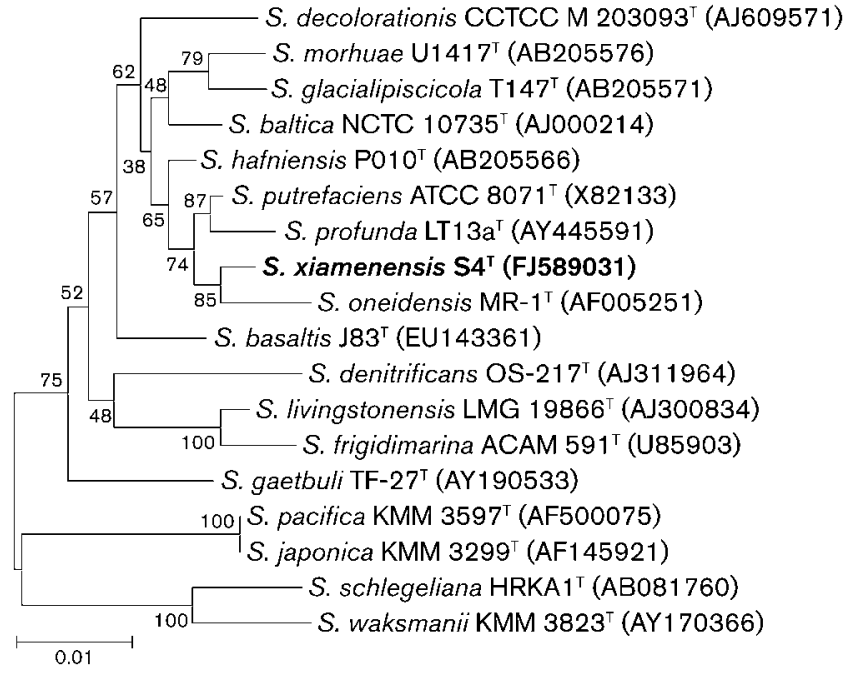

Fig. 1. Phylogenetic placement of strain $S 4^{\top}$ according to $16 \mathrm{~S}$ rRNA gene sequence analysis. The tree was constructed using the neighbour-joining method, and genetic distances were computed from Kimura's two-parameter model. Bootstrap values, expressed as percentages of 1000 replications, are given at branching points. Bar, 0.01 substitutions per nucleotide position.

type strains of recognized Shewanella species. The results showed that strain $\mathrm{S}^{\mathrm{T}}$ exhibited 16S rRNA gene sequence similarity of $91.2-98.8 \%$ to the type strains of the other 49 Shewanella species. Among these, nine type strains showed $16 \mathrm{~S}$ rRNA gene sequence similarity of more than $97 \%$ (97.4-98.8\%) to strain $\mathrm{S}^{\mathrm{T}}$ (Fig. 1). Though the $16 \mathrm{~S}$ rRNA gene sequence is accepted as defining phylogenetic relationships between bacterial species, it sometimes lacks sufficient specificity for the differentiation of close relatives (Venkateswaran et al., 1999; Yamamoto \& Harayama, 1995). Therefore, the more rapidly evolving gyrB gene was employed to distinguish closely related strains. The gyrB gene sequence of strain $\mathrm{S}^{\mathrm{T}}$ exhibited $82.2-91.9 \%$ similarity to those of the type strains of nine closely related Shewanella species (Fig. 2). Only one type strain, Shewanella decolorationis JCM $21555^{\mathrm{T}}$, exhibited gyrB sequence similarity $(91.9 \%)$ above the suggested species cut-off value of $90 \%$ for gyrB sequences within the genus Shewanella (Venkateswaran et al., 1999). However, the ultimate criterion remains DNA-DNA relatedness. DNADNA hybridization indicated that the relatedness of DNA from strain $\mathrm{S} 4^{\mathrm{T}}$ and the nine close relatives was only 11.9$30.4 \%$, well below the $70 \%$ threshold for the definition within a species (Stackebrandt \& Goebel, 1994). 16S rRNA gene and $g y r B$ sequence similarity and DNA-DNA relatedness results are summarized in Supplementary Table S3.

Strain $\mathrm{S} 4^{\mathrm{T}}$ can be distinguished easily from S. oneidensis and $S$. putrefaciens by its capacity to utilize sucrose, maltose, arabinose, D-glucose and caprate. Strain $S 4^{\mathrm{T}}$ cannot grow in the presence of $6 \% \mathrm{NaCl}$, unlike $S$. decolorationis and Shewanella hafniensis (Satomi et al., 2006). Production of gelatinase but not amylase also clearly differentiated strain $\mathrm{S} 4^{\mathrm{T}}$ from $S$. profunda. Strain $\mathrm{S} 4^{\mathrm{T}}$ could grow at $37{ }^{\circ} \mathrm{C}$ and ferment D-glucose, whereas Shewanella baltica, S. hafniensis, S. morhuae and S. glacialipiscicola could not. Therefore, on the basis of phenotypic, chemotaxonomic and phylogenetic data, combined with DNA-DNA relatedness, strain $\mathrm{S}^{\mathrm{T}}$ represents a distinct species within the genus Shewanella, for which the name Shewanella xiamenensis sp. nov. is proposed.

\section{Description of Shewanella xiamenensis sp. nov.}

Shewanella xiamenensis (xia.me.nen'sis. N.L. fem. adj. xiamenensis from Xiamen, China, where the type strain was isolated).

Cells are Gram-negative rods, $0.7-0.8 \times 2.5-4.0 \mu \mathrm{m}$, motile by means of a single polar flagellum. Facultatively anaerobic chemoheterotroph. Endospores are not formed. Colonies on marine agar 2216 are smooth, circular, slightly brown in colour and convex with clear edges. Growth

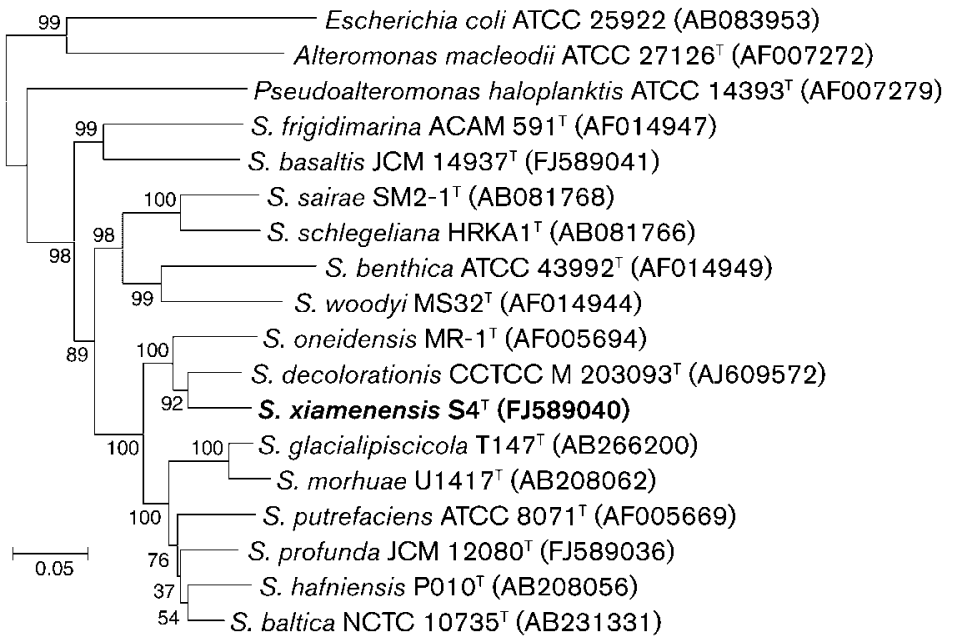

Fig. 2. Phylogenetic placement of strain $S 4^{\top}$ according to $g y r B$ gene sequence analysis. The tree was constructed using the neighbourjoining method, and genetic distances were computed from Kimura's two-parameter model. Bootstrap values, expressed as percentages of 1000 replications, are given at branching points. Bar, 0.05 substitutions per nucleotide position. 
occurs at 4 and $37{ }^{\circ} \mathrm{C}$, but not above $37{ }^{\circ} \mathrm{C}$. The $\mathrm{pH}$ range for growth is 6.0-9.0, with optimum growth around $\mathrm{pH}$ 7.0. Sodium ions are not required for growth; growth occurs in the presence of $0-4 \% \mathrm{NaCl}$ and optimal growth occurs in 1-2\% NaCl. Cells are positive for oxidase, catalase, $N$-acetyl- $\beta$-glucosaminidase, $\alpha$-glucosidase, $\beta$ glucosidase, acid and alkaline phosphatase, leucine aminopeptidase, valine aminopeptidase and naphthol-AS-BIphosphoamidase activities. Cells are able to reduce nitrate, nitrite, TMAO, selenite, fumarate, ferric citrate and ferric oxide with lactate as electron donor. Hydrolysis of gelatin, DNA and Tween 80 is positive; negative for starch hydrolysis. $\mathrm{H}_{2} \mathrm{~S}$ is formed anaerobically from thiosulfate. Fermentation is observed on D-glucose. Utilizes a limited range of carbon sources according to Biolog: $\alpha$-cyclodextrin, dextrin, Tweens 40 and 80, L-arabinose, $\alpha$-D-glucose, maltose, sucrose, acetic acid, formic acid, $\alpha$-hydroxybutyric acid, $\alpha$-ketobutyric acid, DL-lactic acid, succinic acid, bromosuccinic acid, glycyl L-aspartic acid, glycyl Lglutamic acid, L-serine, inosine, uridine and thymidine. Glycogen, $N$-acetyl-D-glucosamine, monomethyl succinate, $\beta$-hydroxybutyric acid, $\gamma$-hydroxybutyric acid, $\alpha$-ketovaleric acid, propionic acid, succinamic acid, L-alanine, L-alanyl glycine, L-leucine and L-threonine are utilized weakly. Both menaquinones and ubiquinones are present, with Q-7 and Q-8 as the predominant ubiquinones and MK-7 as the predominant menaquinone. The main fatty acids are iso- $\mathrm{C}_{15: 0}, \mathrm{C}_{16: 1} \omega 7 c$ and/or iso- $\mathrm{C}_{15: 0} 2-\mathrm{OH}, \mathrm{C}_{16: 0}$ and $\mathrm{C}_{17: 1} \omega 8 c$. The DNA $\mathrm{G}+\mathrm{C}$ content of the type strain is $46 \mathrm{~mol} \%$.

The type strain, S4 ${ }^{\mathrm{T}}$ (=CCTCC M $209017^{\mathrm{T}}=\mathrm{JCM}$ $\left.16212^{\mathrm{T}}\right)$, was isolated from coastal sediment collected off Xiamen, China.

\section{References}

Bozal, N., Montes, M. J., Tudela, E., Jiménez, F. \& Guinea, J. (2002). Shewanella frigidimarina and Shewanella livingstonensis sp. nov. isolated from Antarctic coastal areas. Int J Syst Evol Microbiol 52, 195-205.

Coates, J. D., Bhupathiraju, V. K., Achenbach, L. A., Mclnerney, M. J. \& Lovley, D. R. (2001). Geobacter hydrogenophilus, Geobacter chapellei and Geobacter grbiciae, three new, strictly anaerobic, dissimilatory Fe(III)-reducers. Int J Syst Evol Microbiol 51, 581-588.

Ezaki, T., Hashimoto, Y. \& Yabuuchi, E. (1989). Fluorometric deoxyribonucleic acid-deoxyribonucleic acid hybridization in microdilution wells as an alternative to membrane filter hybridization in which radioisotopes are used to determine genetic relatedness among bacterial strains. Int J Syst Bacteriol 39, 224-229.

Fonnesbech Vogel, B., Venkateswaran, K., Satomi, M. \& Gram, L. (2005). Identification of Shewanella baltica as the most important $\mathrm{H}_{2} \mathrm{~S}$-producing species during iced storage of Danish marine fish. Appl Environ Microbiol 71, 6689-6697.

Hau, H. H. \& Gralnick, J. A. (2007). Ecology and biotechnology of the genus Shewanella. Annu Rev Microbiol 61, 237-258.

MacDonell, M. T. \& Colwell, R. R. (1985). Phylogeny of the Vibrionaceae, and recommendation for two new genera, Listonella and Shewanella. Syst Appl Microbiol 6, 171-182.
Makemson, J. C., Fulayfil, N. R., Landry, W., Van Ert, L. M., Wimpee, C. F., Widder, E. A. \& Case, J. F. (1997). Shewanella woodyi sp. nov., an exclusively respiratory luminous bacterium isolated from the Alboran Sea. Int J Syst Bacteriol 47, 1034-1039.

Moser, D. P. \& Nealson, K. H. (1996). Growth of the facultative anaerobe Shewanella putrefaciens by elemental sulfur reduction. Appl Environ Microbiol 62, 2100-2105.

Myers, C. R. \& Nealson, K. H. (1990). Respiration-linked proton translocation coupled to anaerobic reduction of manganese(IV) and iron(III) in Shewanella putrefaciens MR-1. J Bacteriol 172, 62326238.

Nealson, K. H. \& Scott, J. (2006). Ecophysiology of the genus Shewanella. In The Prokaryotes: a Handbook on the Biology of Bacteria, 3rd edn, vol. 6, pp. 1133-1151. Edited by M. Dworkin, S. Falkow, E. Rosenberg, K. H. Schleifer \& E. Stackebrandt. New York: Springer.

Nozue, H., Hayashi, T., Hashimoto, Y., Ezaki, T., Hamasaki, K., Ohwada, K. \& Terawaki, Y. (1992). Isolation and characterization of Shewanella alga from human clinical specimens and emendation of the description of S. alga Simidu et al., 1990, 335. Int J Syst Bacteriol 42, 628-634.

Satomi, M., Oikawa, H. \& Yano, Y. (2003). Shewanella marinintestina sp. nov., Shewanella schlegeliana sp. nov. and Shewanella sairae sp. nov., novel eicosapentaenoic-acid-producing marine bacteria isolated from sea-animal intestines. Int J Syst Evol Microbiol 53, 491499.

Satomi, M., Fonnesbech Vogel, B., Gram, L. \& Venkateswaran, K. (2006). Shewanella hafniensis sp. nov. and Shewanella morhuae sp. nov., isolated from marine fish of the Baltic Sea. Int J Syst Evol Microbiol 56, 243-249.

Satomi, M., Fonnesbech Vogel, B., Venkateswaran, K. \& Gram, L. (2007). Description of Shewanella glacialipiscicola sp. nov. and Shewanella algidipiscicola sp. nov., isolated from marine fish of the Danish Baltic Sea, and proposal that Shewanella affinis is a later heterotypic synonym of Shewanella colwelliana. Int J Syst Evol Microbiol 57, 347-352.

Smibert, R. M. \& Krieg, N. R. (1994). Phenotypic characterization. In Methods for General and Molecular Bacteriology, pp. 607-654. Edited by P. Gerhardt, R. G. E. Murray, W. A. Wood \& N. R. Krieg. Washington, DC: American Society for Microbiology.

Stackebrandt, E. \& Goebel, B. M. (1994). Taxonomic note: a place for DNA-DNA reassociation and $16 \mathrm{~S}$ rRNA sequence analysis in the present species definition in bacteriology. Int J Syst Bacteriol 44, 846849.

Svetashev, V. I., Vysotskii, M. V., Ivanova, E. P. \& Mikhailov, V. V. (1995). Cellular fatty acids of Alteromonas species. Syst Appl Microbiol 18, 37-43.

Tamaoka, J. \& Komagata, K. (1984). Determination of DNA base composition by reversed-phase high-performance liquid chromatography. FEMS Microbiol Lett 25, 125-128.

Tamura, K., Dudley, J., Nei, M. \& Kumar, S. (2007). MEGA4: molecular evolutionary genetics analysis (MEGA) software version 4.0. Mol Biol Evol 24, 1596-1599.

Toffin, L., Bidault, A., Pignet, P., Tindall, B. J., Slobodkin, A., Kato, C. \& Prieur, D. (2004). Shewanella profunda sp. nov., isolated from deep marine sediment of the Nankai Trough. Int J Syst Evol Microbiol 54, 1943-1949.

Venkateswaran, K., Moser, D. P., Dollhopf, M. E., Lies, D. P., Saffarini, D. A., MacGregor, B. J., Ringelberg, D. B., White, D. C., Nishijima, M. \& other authors (1999). Polyphasic taxonomy of the genus Shewanella and description of Shewanella oneidensis sp. nov. Int J Syst Bacteriol 49, 705-724. 
Xu, M., Guo, J., Cen, Y., Zhong, X., Cao, W. \& Sun, G. (2005) Shewanella decolorationis sp. nov., a dye-decolorizing bacterium isolated from activated sludge of a waste-water treatment plant. Int $J$ Syst Evol Microbiol 55, 363-368.

Yamamoto, S. \& Harayama, S. (1995). PCR amplification and direct sequencing of $g y r B$ genes with universal primers and their application to the detection and taxonomic analysis of Pseudomonas putida strains. Appl Environ Microbiol 61, 1104-1109.

Ziemke, F., Höfle, M. G., Lalucat, J. \& Rosselló-Mora, R. (1998). Reclassification of Shewanella putrefaciens Owen's genomic group II as Shewanella baltica sp. nov. Int J Syst Bacteriol 48, 179186. 